\title{
DARI RUWAT LAUTMENJADI SYUKURAN LAUTS STRATEGI MEMPERTAHANKAN KELANGSUNGAN TRADISI masyarakat Nelayan pulaU JaWa DI KABUpATEN LAMPUNG SELATAN
}

\author{
FROM RUWAT LAUT TO SYUKURAN LAUT: \\ STRATEGY OF THE SUSTAINABILITY OF THE JAVANESE FISHERMEN \\ TRADITIONS IN SOUTH LAMPUNG REGENCY
}

\author{
Irvan Setiawan \\ Balai Pelestarian Nilai Budaya Jawa Barat \\ Jl. Cinambo No. 136, Ujungberung, Bandung. \\ e-mail: kamaliasetiawan@yahoo.co.id

\begin{abstract}
Abstrak
Masyarakat nelayan di Kabupaten Lampung Selatan sebagian besar berasal dari tanah Jawa yang datang ke Lampung dengan berbagai cara. Salah satunya melalui program transmigrasi yang dilakukan sejak zaman penjajahan. Selain melakukan aktivitas sebagai nelayan, aktivitas budaya juga menjadi bagian dari kehidupan masyarakat nelayan tersebut, salah satunya adalah Ruwat Laut. Setelah dilaksanakan selama bertahun-tahun, Ruwat Laut berganti nama menjadi Syukuran Laut. Perubahan nama tersebut menjadi hal menarik untuk diteliti. Penelitian dilakukan dengan menggunakan metode deskriptif dengan pendekatan kualitatif. Hasil yang diperoleh adalah bahwa pergantian nama dari Ruwat Laut menjadi Syukuran Laut disebabkan kekurangan dana dan perbedaan persepsi antara adat masyarakat dari tanah Jawa dengan adat masyarakat Lampung. Syukuran Laut dilakukan dengan meniadakan tahapan tradisi yang dianggap menjadi penyebab Ruwat Laut tidak terlaksana, yaitu pelarungan kepala kerbau, pertunjukan wayang golek, dan berbagai jenis kegiatan yang membutuhkan dana cukup besar.
\end{abstract}

Kata kunci: Ruwat Laut, Syukuran Laut, transmigrasi.

\begin{abstract}
The fishermen communities in South Lampung Regency were once mostly the Javanese who migrated to settle in Lampung in various ways. One of those was through the transmigration program since the colonial era. It was one rewarding way in which many of those have migrated since the era. In addition to doing their activities as the fishermen, they have also carried on their cultural activities as a part of their fishermen life community, that is, Ruwat Laut. After being carried out for years, Ruwat Laut was renamed Syukuran Laut. The name change is interesting for a research. The study was conducted by using a descriptive method with qualitative approach. The studies reveal that the change name was due to lack of funding and perceptual difference between customs of Java and customs of Lampung. Syukuran Laut is carried out without those traditions that once prevented Ruwat Laut, namely buffalo head offering, puppet show, and various types of activities with substantial funds.
\end{abstract}

Keywords: ruwat laut, syukuran laut, transmigration.

\section{A. PENDAhuluan}

Berbicara mengenai apa saja karya budaya dari suatu kelompok masyarakat akan sangat sulit ditemukan jawabannya. Proses perjalanan sebuah kebudayaan turut menyertakan berbagai komponen kebudayaan termasuk di dalamnya komponen-komponen yang menciptakan 
sebuah karya budaya. Hal ini memang menjadi sebuah persoalan tatkala sebuah karya budaya di suatu daerah dan diakui sebagai produk asli wilayah mereka. Namun ternyata, di daerah lainnya juga ditemukan karya budaya yang mirip sehingga menimbulkan perdebatan mengenai kepemilikan sah dari karya budaya tersebut. Seperti halnya dalam rapat sidang WBTB tahun 2018. Salah satu karya budaya yang diusulkan oleh Provinsi Kalimantan Timur ternyata merupakan karya budaya yang berasal dari Suku Bangsa Bugis yang sejak lama telah bermigrasi dan berbaur dengan budaya penduduk setempat sehingga menciptakan karya budaya khas masyarakat di Kalimantan Timur.

Proses perpindahan penduduk, baik dilakukan dalam bentuk transmigrasi, urbanisasi, atau apa pun namanya memang kerap menjadi sebuah pemicu dari munculnya sebuah karya budaya baru di daerah baru yang ternyata sumber penciptaannya berasal dari daerah asal mereka. Sama persis dari karya budaya baru tersebut memang tidak menjadi jaminan karena mereka yang pindah ke daerah baru tersebut akan mendapat "uji kelayakan" dari beberapa kriteria yang diajukan masyarakat setempat. Hal pertama yang akan "diuji" tentunya adalah perilaku sosial dan budaya masyarakat pendatang. Semakin banyak kesesuaian maka masyarakat pendatang akan semakin diterima oleh masyarakat setempat. Apabila ada ketidaksesuaian atau kesepahaman maka dapat saja menimbulkan konflik. Dua contoh kasus yang dalam hal ini adalah konflik sosial berlatarbelakang etnis adalah di Kalimantan antara masyarakat Madura dengan masyarakat Dayak, dan di Lampung yaitu antara masyarakat Bali dengan masyarakat Lampung.

Pola-pola perpindahan penduduk yang dilakukan dalam bentuk transmigrasi, yang biasanya ditempatkan dalam suatu wilayah secara berkelompok, apalagi dilatarbelakangi oleh sebuah kebudayaan yang sama maka akan sangat memungkinkan terjadinya ide untuk melestarikan karya budaya mereka di lingkungan yang baru tersebut. Seperti halnya transmigran masyarakat Jawa di Provinsi Lampung yang dilakukan dengan pola penempatan mengelompok. Selain karya budaya, mereka bahkan menamai wilayahnya sesuai dengan wilayah saat mereka tinggal di daerah asal (Jawa).

Satu dari sekian banyak wilayah transmigrasi di Indonesia yang banyak melakukan kegiatan budaya asal mereka adalah di Provinsi Lampung, tepatnya di Kabupaten Lampung Selatan. Di Kabupaten Lampung Selatan setidaknya ada tiga pendukung kebudayaan para transmigran, yaitu Sunda, Jawa, dan Bali. Dua yang pertama, yaitu Sunda dan Jawa memiliki beberapa kesamaan budaya sehingga banyak menampilkan karya budaya serupa di lokasi baru tersebut. Satu perbedaan yang sangat kentara tentunya adalah bahasa yang dipergunakan, yaitu bahasa Sunda dan bahasa Jawa. Tradisi daur hidup, dan tradisi ruwatan adalah dua di antara sekian banyak karya budaya yang memiliki kesamaan antara masyarakat Jawa dan Sunda.

Pergelaran atau pelaksanaan karya budaya dari kedua wilayah budaya tersebut sejak dahulu hingga kini masih tetap dilakukan di wilayah Kabupaten Lampung Selatan. Kata "dahulu" bersifat relatif karena melibatkan banyak definisi. Penulis dalam hal ini berpegang pada definisi yang dikeluarkan oleh Direktorat Jenderal Kebudayaan melalui Direktorat Warisan dan Diplomasi Budaya $(\mathrm{WDB})^{1}$ yaitu berusia 50 tahun atau dua generasi. Berpegang pada definisi tersebut, pergelaran dan pelaksanaan karya budaya masyarakat Sunda dan Jawa di Kabupaten Lampung Selatan tentunya sudah berusia

\footnotetext{
${ }^{1}$ Saat ini Direktorat Warisan dan Diplomasi Budaya (WDB) dilebur menjadi empat direktorat baru sebagai hasil dari peraturan pemerintah untuk merampingkan jumlah eselon.
} 
di atas 50 tahun atau dua generasi. Mereka (Masyarakat Sunda dan Jawa) sudah melakukan transmigrasi ke Kabupaten Lampung Selatan sejak dimulainya periode transmigrasi pertama yang dilakukan oleh pemerintah kolonial Belanda, yaitu pada tahun 1905. Kemudian dilakukan lagi pada periode kedua. Masa kemerdekaan, transmigrasi dari masyarakat Sunda dan Jawa kembali dilakukan baik pada masa Orde Lama, Orde Baru, maupun dalam masa pemerintahan saat ini.

Dari sekian lamanya masyarakat Sunda dan Jawa bermukim di Kabupaten Lampung Selatan, timbul pertanyaan, apakah keberadaan mereka sepenuhnya diterima oleh Masyarakat Asli Lampung (Saibatin dan Pepadun)?

Seperti dikemukakan di atas bahwa masyarakat setempat (Masyarakat Lampung) sebagai "pemilik wilayah budaya" dan masyarakat pendatang akan mencari kesepahaman budaya. Hasil yang diperoleh adalah terciptanya varian-varian yang bersumber dari karya budaya asli masyarakat pendatang (Sunda dan Jawa). Karakter budaya Masyarakat Lampung yang banyak berpedoman pada ajaran agama Islam terkadang mengalami benturan tatkala berhadapan dengan budaya masyarakat pendatang yang dalam beberapa segi dianggap bertentangan. Varian-varian dari karya budaya masyarakat pendatang merupakan hasil dari upaya kesepahaman yang dilakukan agar praktik kebudayaan masyarakat pendatang dapat terus berjalan. Namun, apakah setelah sekian lama upaya kesepahaman ini dilakukan akan tetap berlaku kata sepakat dari masyarakat Lampung untuk menyetujui sepenuhnya varian karya budaya dari masyarakat pendatang tersebut? Pertanyaan-pertanyaan seputar kehidupan sosial budaya masyarakat pendatang memang seakan tidak akan pernah habis karena sebuah kesepahaman sebenarnya bersifat relatif akibat banyak yang diputuskan secara lisan dan biasanya hanya bertahan sampai akhir periode mereka yang memutuskan. Apakah periode selanjutnya tetap sama? Belum tentu juga karena harus ada proses resosialisasi kembali agar apa yang sudah disepakati dapat tetap berlaku di periode selanjutnya.

Salah satu bentuk karya budaya yang hingga saat ini masih dapat dikatakan mengalami proses re-sosialisasi agar terjadi kesepahaman antara masyarakat pendatang dengan masyarakat Lampung adalah ritual Ruwat Laut. Ada juga yang menyebut dengan istilah Pesta Laut, sedangkan Masyarakat Lampung menyebut ritual tersebut dengan nama Ngumbai Lawok (Ruslan, 2019:133-155). Meskipun ada beberapa nama, namun pola pelaksanaan tetaplah sama, terutama pada acara inti yaitu pelarungan kepala kerbau ke tengah laut. Tujuan dilarungkannya kepala kerbau tersebut adalah sebagai sebuah persembahan atau penghormatan kepada penguasa laut agar memberikan keselamatan dan rezeki berlimpah kepada para nelayan dan jenis pekerjaan lainnya yang erat hubungannya dengan laut.

Kondisi kekinian, ritual Ruwat Laut terutama di Desa Sukaraja Kecamatan Rajabasa Kabupaten Lampung Selatan diganti menjadi Syukuran Laut. Hal ini tentu menimbulkan pertanyaan karena ritual Ruwat Laut yang telah berjalan cukup lama di wilayah masyarakat nelayan pendatang di Kabupaten Lampung Selatan ini harus berganti nama menjadi Syukuran Laut. Beranjak dari apa yang terurai di atas, ada satu poin masalah yang hendak dijelaskan dalam tulisan ini, yaitu: Bagaimana latar belakang penggantian nama dari Ruwat Laut menjadi Syukuran Laut?

\section{B. METODE PENELITIAN}

Penelitian ini dimulai dengan mencari referensi terkait. Salah satunya referensi dari tulisan Tatiek Kartikasari (Tatiek, 1999) yang memberikan wawasan tentang ritual Ruwat Laut. Meskipun lokasi penelitian berada di wilayah Pangandaran Provinsi Jawa Barat namun dari hasil 
penelitian banyak diperoleh kesamaan di antara kedua lokasi yang berbeda tersebut.

Penelitian tentang Ruwat Laut juga sudah dilakukan salah satunya oleh Saputra (2014) yang berjudul "Tradisi Ruwatan Laut (Ngumbai Lawok) di Kelurahan Kangkung Kecamatan Teluk Betung Selatan Kota Bandar Lampung dalam Perspektif Hukum Islam". Kelurahan Kebon Kangkung juga menjadi lokasi penelitian yang dilakukan oleh Ruslan (2014). Mengambil topik tentang makna sedekah laut, Ruslan mencoba mengungkap "uji kesepahaman" antara pelaku tradisi Sedekah Laut yang tidak lain adalah Ruwat Laut yang berasal dari masyarakat nelayan Cirebon terhadap masyarakat Lampung yang berada di Kelurahan Kebon Kangkung, Kecamatan Bumi Waras, Kota Bandar Lampung. Hasil penelitian Saputra, Ruslan, dan Tatiek Kartikasari secara garis besar memiliki persamaan baik sebelum, saat pelaksanaan, maupun setelah pelaksanaan ritual Ruwat Laut.

Metode penelitian yang digunakan adalah dengan melakukan pendekatan deskriptif kualitatif dengan tujuan untuk memberikan gambaran yang sistematis dan faktual tentang fenomena-fenomena yang ada sehingga mengakibatkan pergantian nama Ruwat Laut menjadi Syukuran Laut.

Untuk mendukung data penelitian dilakukan pencarian data primer dan sekunder. Data sekunder diperoleh dengan mencari di perpustakaan dan melakukan pencarian sumber internet terhadap berbagai sumber penelitian terkait dengan topik yang akan diteliti. Data sekunder diperoleh dengan cara observasi dan wawancara di lapangan. Saat berada di lapangan, beberapa instrumen yang dibawa adalah pedoman wawancara, alat rekam audio video. Pedoman wawancara digunakan untuk mengarahkan pertanyaan sehingga dapat terfokus pada data-data yang sangat diperlukan dalam penelitian ini. Perekam audio video sangat berguna untuk merekam data-data yang diperoleh dari informan serta mencatat dalam bentuk visual saat melakukan observasi atau pengamatan lapangan.

Lokasi yang menjadi sasaran penelitian berada di Desa Sukaraja, Kecamatan Rajabasa, Kabupaten Lampung Selatan, Provinsi Lampung. Pemilihan lokasi tersebut didasarkan adanya aktivitas Ruwat Laut pada masa lalu dan saat ini berganti nama menjadi Syukuran Laut.

\section{HASIL DAN BAHASAN}

\section{Gambaran Umum Lokasi Penelitian}

Lampung adalah salah satu provinsi di Indonesia yang memiliki perjalanan sejarah menarik baik dari segi kondisi geografis, kependudukan, maupun persebaran budayanya. Kemenarikan dari kondisi geografis dapat dilihat dari adanya Gunung Krakatau yang pernah menghubungkan antara Pulau Jawa dan Sumatera, dan pada akhirnya meletus hingga mengakibatkan terbentuknya dua pulau besar yang kemudian ditetapkan menjadi pembatas geografis antara Provinsi Lampung dengan Provinsi Banten.

Perjalanan wilayah Lampung Selatan menjadi sebuah kabupaten yang berada dalam lingkup wilayah administratif Provinsi Lampung dilalui kronologi penetapan surat dan undangundang yang cukup panjang. Dari kronologis peristiwa administratif ke wilayah akhirnya ditetapkan terbentuknya Kabupaten Lampung Selatan pada tanggal tanggal 14 November 1956 dengan ibukotanya saat itu berada di Tanjung Karang - Teluk Betung. Saat ini daerah tersebut bernama Kota Bandar Lampung.

Masyarakat Lampung sejak zaman dahulu sudah mengalami pertemuan budaya dengan suku bangsa lain. Hal ini tercermin dari kata "Lampung". Banyak teori dan versi yang mencoba untuk menelaah asal mula nama Lampung. Silaban mengemukakan bahwa ada sekitar 3 versi yang mencoba menerjemahkan asal mula nama Lampung (Silaban, 1997: 4-6). Salah satunya seperti yang dikemukakan oleh Hilman Hadikesuma dalam Seminar 
Sejarah Lampung Tahun 1976. Beliau mengatakan bahwa kata Lampung berasal dari dua kata yaitu To-lang dan P'o-hwang. Dua kata tersebut, setelah dihilangkan suku kata To berbunyi "Langphwang" (Lang P'o-hwang).

Unsur legenda juga menjadi salah satu bagian dari asal mula nama "Lampung". Residen Belanda untuk Lampung kala itu bernama J.A. Dubois menghubungkannya dengan Kerajaan Majapahit. Dikatakannya bahwa Tuhan menurunkan orang pertama ke bumi bernama Sang Dewa Senembahan dan Widodari Simuhun. Dari pasangan tersebut lahir keturunan bernama Si Jawa, Ratu Majapahit, Sipasundayang, Ratu Pajajaran dan Si Lampung, Ratu Balau. Dubois mencoba untuk mengartikannya dan membuahkan asumsi bahwa kata Lampung berasal dari op het water drijven (terapungapung di atas air).

Legenda lainnya mencoba mengaitkan kata "Lampung" dengan kata "Lappung". "Lappung" merupakan istilah atau kata yang biasa dipergunakan masyarakat Lampung asli di daerah Belalau, Menggala, dan Abung untuk menyebutkan kata Lampung. Kata "Lappung" kemudian dikaitkan dengan bahasa dan legenda Batak tentang empat saudara yang menyelamatkan diri menggunakan rakit akibat meletusnya Gunung berapi di wilayah Batak ${ }^{2}$. Salah satu dari empat bersaudara tersebut bernama Ompung-Silamponga terdampar di Krui, tepatnya di wilayah dataran tinggi Belalau atau Sekala Brak. Hamparan tanah yang luas dan indah membuat OmpungSilamponga berteriak "Lappung" yang dalam bahasa Tapanuli berarti luas. Pendapat berbeda mengatakan bahwa kata Lampung malah berasal dari nama Ompung-Silamponga sendiri. Berbagai versi mengenai asal mula nama Lampung

2 Kawah dari gunung berapi tersebut menjadi sebuah danau yang bernama Danau Toba. adalah relatif karena hingga saat ini pencarian identitas masih terus berjalan.

\section{a. Kondisi Geografis}

Daerah Kabupaten Lampung Selatan mempunyai daerah daratan kurang lebih $2.007,01 \mathrm{~km}^{2}$, dengan kantor Pusat Pemerintahan di Kota Kalianda, yang diresmikan menjadi ibu kota Kabupaten Lampung Selatan oleh Menteri Dalam Negeri pada tanggal 11 Februari 1982. Sampai saat ini Kabupaten Lampung Selatan telah mengalami pemekaran dua kali. Pertama berdasarkan Undang-undang Nomor 2 tahun 1997 yang ditetapkan pada tanggal 3 Januari 1997 tentang pembentukan Kabupaten Tanggamus. Kemudian yang kedua berdasarkan Undang-Undang Republik Indonesia Nomor 33 Tahun 2008 tentang Pembentukan Kabupaten Pesawaran tanggal 10 Agustus 2008.

Melalui berbagai peraturan yang mensahkan pembentukan wilayah baru setidaknya akan menambah jumlah wilayah kecamatan pula. Upaya pemekaran di Kabupaten Lampung Selatan dimaksudkan agar pemerataan pembangunan di segala bidang dapat dilaksanakan. Dengan dibentuknya bidang administrasi baru, rangkaian kantor pemerintah baik dinas pendidikan, KUA, Koperasi, dan sebagainya dapat lebih menyebar dan diharapkan dapat melayani masyarakat secara lebih merata di 17 kecamatan.

Wilayah administrasi Kabupaten Lampung Selatan mempunyai batas-batas sebagai berikut:

- Sebelah Utara : berbatasan dengan wilayah Kabupaten Lampung Tengah dan Lampung Timur;

- Sebelah Selatan : berbatasan dengan Selat Sunda;

- Sebelah Barat : berbatasan dengan wilayah Kabupaten Pesawaran;

- Sebelah Timur : berbatasan dengan Laut Jawa.

Sebagaimana diketahui bahwa Lampung Selatan memiliki wilayah 
kepulauan yang tersebar di Selat Sunda dan Laut Jawa. Beberapa pulau cukup terkenal yang menjadi bagian dari Kabupaten Lampung Selatan di antaranya Anak Krakatau, Sebuku, dan Sebesi. Sementara untuk pulau-pulau yang berada dalam wilayah Kecamatan Rajabasa adalah pulau-pulau yang terdapat di Kabupaten Lampung Selatan antara lain Pulau Krakatau, Pulau Sebesi, Pulau Sebuku, Pulau Rimau dan Pulau Kandang.

Anak Krakatau pernah beberapa kali erupsi dan menimbulkan tsunami. Bencana alam tersebut menimpa pulau lainnya, dan yang cukup menderita karena adanya masyarakat yang tinggal di pulau tersebut, yaitu Pulau Sebuku dan Sebesi.

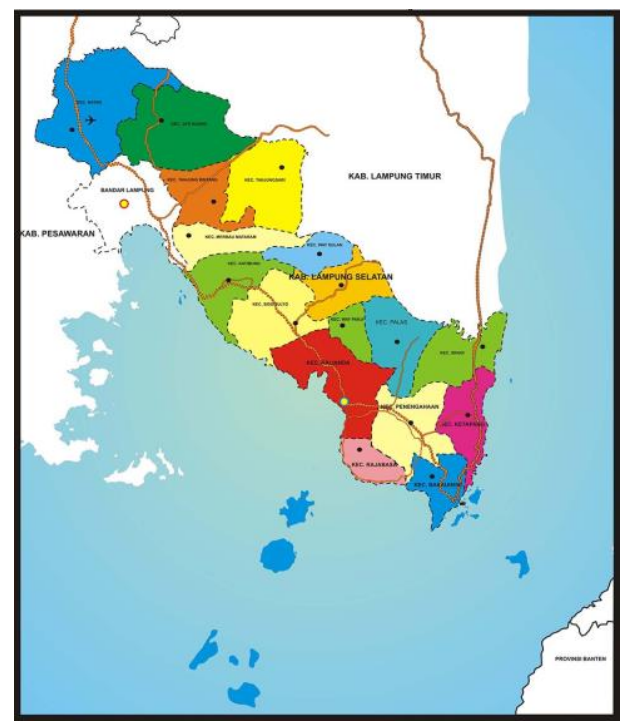

Gambar 1. Peta Kab. Lampung Selatan Sumber: BPS Kab. Lampung Selatan 2018.

Pulau Sebesi merupakan salah satu pulau terbesar dalam wilayah Kabupaten Lampung Selatan yang terkena dampak cukup parah bencana tsunami beberapa waktu lalu. Pulau ini berada di posisi paling dekat dengan gugusan Pegunungan Krakatau dan dihuni sekitar 2.875 orang (data tahun 2018). Namun, jumlah penduduk tersebut secara drastis berkurang menjadi sekitar 400 orang akibat bencana tsunami.
Dari segi kewilayahan, beberapa kecamatan di Kabupaten Lampung Selatan adalah berbatasan dengan laut. Kondisi geografis Lampung Selatan yang berdekatan dengan Pulau Anak Krakatau mengakibatkan wilayah tersebut ikut terkena dampak tsunami beberapa tahun lalu. Adapun wilayah yang terkena dampak adalah Kecamatan Kalianda, Rajabasa, Bakauheni, dan Ketapang. Dampak tsunami yang ditimbulkan mengakibatkan sarana dan prasarana di wilayah tersebut rusak disertai dengan adanya korban jiwa. Data terdampak atau berpotensi tsunami lebih jelasnya dapat dilihat pada tabel di bawah ini.

Tabel 1. Daerah Potensi Bencana menurut Kecamatan di Kabupaten Lampung Selatan, 2017

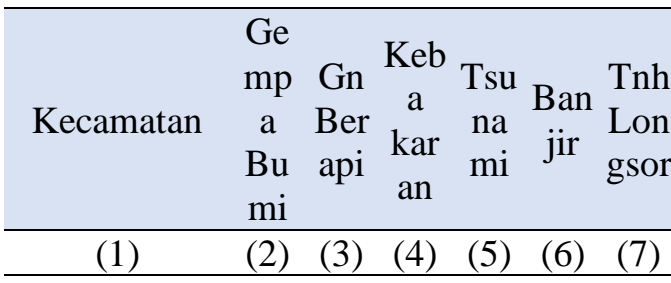

\begin{tabular}{lcccccc}
\hline Natar & - & - & V & - & V & - \\
\hline Jati_Agung & - & - & - & - & - & - \\
\hline $\begin{array}{l}\text { Tanjung_Bin- } \\
\text { tang }\end{array}$ & - & - & V & - & V & - \\
\hline Tanjung_Sari & - & - & - & - & V & - \\
\hline Katibung & - & - & - & V & V & V \\
\hline Merbau_Mata- & - & - & V & - & - & V \\
ram & & & & & & \\
\hline Way_Sulan & - & - & - & - & V & - \\
\hline Sidomulyo & - & V & - & - & V & - \\
\hline Candipuro & - & - & - & - & V & - \\
\hline Way_Panji & - & - & - & - & V & - \\
\hline Kalianda & - & - & V & V & V & V \\
\hline Rajabasa & V & V & V & V & V & V \\
\hline Palas & - & - & V & - & V & - \\
\hline Sragi & - & - & V & V & V & V \\
\hline Penengahan & - & V & V & - & V & V \\
\hline Ketapang & - & - & V & V & V & V \\
\hline Bakauheni & V & - & V & V & V & V
\end{tabular}

Sumber : IPDS BPS Kabupaten Lampung Selatan, 2018. 
Berdasarkan tabel di atas bahwa selain kecamatan tersebut di atas, kecamatan lain yang terdampak tsunami adalah Kecamatan Katibung. Katibung merupakan sebuah kecamatan yang cukup jauh dari pusat bencana (tsunami), namun arus gelombang tsunami ternyata dapat mencapai kecamatan tersebut.

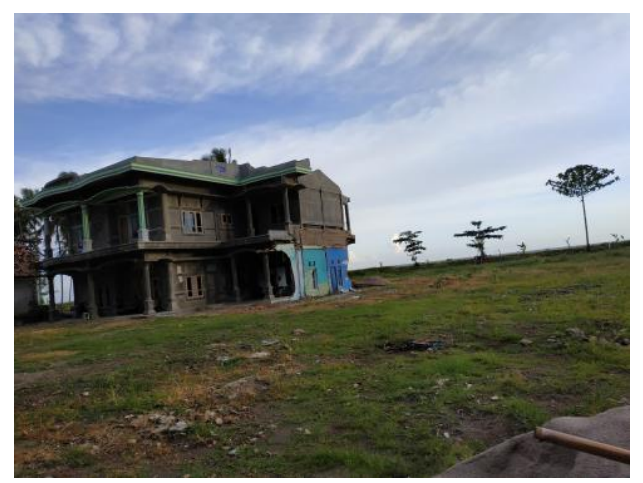

Gambar : Salah satu rumah terdampak tsunami di Kab. Lampung Selatan.

Sumber: Dokumentasi BPNB Jabar, 2019

Bencana alam dalam bentuk banjir rob, sungai, hingga tsunami dikategorikan sebagai bencana yang disebabkan tingkat ketinggian daratan dari permukaan air laut. Beberapa kecamatan yang berpotensi tsunami. Tiga kecamatan di antaranya, yaitu Kecamatan Ketapang, Bakauheni, dan Rajabasa memiliki ketinggian daratan hanya berkisar 1 hingga 6 meter saja dari permukaan air laut. Oleh karena itu posisi 3 kecamatan yang berbatasan dengan laut tersebut tentunya akan sangat besar potensinya terhadap bencana tsunami.

\section{b. Kependudukan}

Arena interaksi antarwarga merupakan dinamika kependudukan yang dapat dilakukan dengan berbagai cara dan lokasi. Interaksi dari hanya sekadar bercengkrama membicarakan hal yang ringan hingga berat terjadi di banyak suasana. Satu yang menjadi alat utama interaksi adalah komunikasi yang dipahami oleh kedua belah pihak.

Lampung merupakan salah satu provinsi yang dapat dikatakan sebagai miniatur Indonesia karena dihuni oleh masyarakat dari berbagai sukubangsa yang datang dan menetap di Lampung. Secara otomatis, kehidupan berinteraksi di antara warga menuntut mereka untuk berkomunikasi dengan bahasa yang dapat dipahami oleh kedua belah pihak.

Penduduk pendatang mendominasi hampir $84 \%$. Kelompok etnik terbesar : Jawa (30\%), Banten/Sunda (20\%), Lampung Asli (16\%), Semendo (12\%), Minangkabau (10\%). Kelompok etnis lain yang juga cukup banyak jumlahnya adalah Bali, Batak, Bengkulu, Bugis, Cina, Ambon, Aceh, Riau, dan lain-lain. Kepindahan dari tempat asal ke tempat yang baru membawa dampak terjadinya perubahan dalam mata pencaharian dan kebiasaan hidup (Wiryawan et.al, 1999: 44).

Pada masa kolonisasi, Kabupaten Lampung Selatan sejak zaman penjajahan Belanda dihuni tidak saja masyarakat asli Lampung yang saat ini dikenal dua kemargaan yaitu Marga Saibatin dan Marga Pepadun. Ada dua kelompok wilayah masyarakat yang dapat dikatakan memiliki sisi historis yang cukup kental dan mewarnai kehidupan bermasyarakat di Provinsi Lampung, yaitu masyarakat wilayah Provinsi Banten, Provinsi Jawa Barat, dan masyarakat di wilayah Provinsi Jawa Tengah.

Banten menjadi masyarakat pendatang yang mewarnai kehidupan bermasyarakat di Provinsi Lampung sejak masa penjajahan. Sebelum terjadinya pemekaran, Provinsi Banten masih tergabung dengan Provinsi Jawa Barat. Kesamaan wilayah kala itu dapat diasumsikan bahwa kedua provinsi tersebut (Jawa Barat dan Banten) juga memiliki kesamaan dalam budaya, yaitu budaya Sunda.

Awal dari proses masuknya Banten ke Lampung di antaranya karena upaya penyebaran agama Islam ke wilayah Lampung. Fatahillah sebagai Sultan Banten kala itu menikah dengan putri dari Minak Raja Jalan, Ratu dari Keratuan Pugung (sekarang ternasuk wilayah 
Kecamatan Jabung, Kabupaten Lampung Tengah) yang bernama Puteri Sinar Alam. Pernikahan lebih dilatarbelakangi oleh unsur politis dalam upaya menarik warga Lampung untuk bergabung dengan Banten dalam melawan Portugis. Sisi lainnya, Fatahillah beserta dengan para ulama juga secara aktif menyebarkan agama Islam pada masyarakat Lampung (Tatiek, 1999: 44-45). Dengan demikian, hubungan antara masyarakat Lampung dengan masyarakat Banten hingga saat ini masih memiliki keterikatan historis dan religi.

Selain masyarakat Banten, masyarakat Sunda di Provinsi Jawa Barat dan masyarakat Jawa di Provinsi Jawa Tengah juga turut mewarnai kehidupan masyarakat di Lampung yang sebagian besar dilatarbelakangi oleh program transmigrasi. Politik transmigrasi pada saat itu sudah diterapkan di wilayah Kabupaten Lampung Selatan. Penduduk yang dipindahkan oleh Belanda kala itu sebagian besar dari Pulau Jawa. Latar belakang perpindahan penduduk Pulau Jawa ke Lampung Selatan lebih disebabkan kolonisasi Belanda yang hendak membuka wilayah baik permukiman maupun perkebunan. Istilah pada waktu itu bukan transmigrasi namun menggunakan istilah kolonisasi. Lembaga yang mengurusi masalah tersebut bernama Centraal Commissie voor Emmigratie en Kolonisatie van Inheemsen.

Proses pembukaan lahan yang membutuhkan banyak tenaga kerja membuat Belanda mengambil politik memindahkan penduduk di wilayah yang cukup padat ke wilayah sasaran. Politik memindahkan penduduk atau juga disebut transmigrasi pertama Belanda ke Lampung dilaksanakan pada tahun 1905-1911. Salah satu alasan program transmigrasi yang dijalankan Belanda pada waktu itu adalah bahwa jumlah penduduk di Pulau Jawa sudah mencapai 28.746.638 jiwa, dan pada tahun 1920 sudah mencapai 34.984.171 jiwa (Kartodirdjo et.al, 1973:8-10). Jumlah tersebut dapat dikatakan sangat padat apabila dibandingkan dengan masyarakat yang menghuni pulau-pulau besar lainnya terutama Sumatera dan Kalimantan.

Berbagai persiapan untuk program transmigrasi pun dilakukan, di antaranya wilayah relokasi penduduk dari Pulau Jawa. Sasaran wilayah tersebut di antaranya Pulau Sumatera yang meliputi daerah di Sumatera Barat, Bengkulu, Palembang, dan Lampung. Sarana dan prasarana dalam melakukan program tersebut seperti diungkap oleh Dahlan meliputi tunjangan per kepala keluarga, transportasi, pembelian alat-alat dapur, alat-alat pertanian, pembangunan rumah tinggal bagi para emigran, pembangunan rumah petugas kesehatan (dokter dari kalangan pribumi), pengadaan bibit tanaman, gaji-gaji (dokter Jawa, kontrolir, asisten wedana, juru tulis, opas, mantri irigasi, kuli ukur, kepala desa, dan pamongpraja), biaya perjalanan (bagi petugas kesehatan, petugas keamanan, mantri irigasi, asisten wedana, juru tulis, dan kontrolir). Tunjangan atau premi per keluarga yang dimaksud adalah berupa sejumlah uang berkisar antara 20-22,5 gulden per keluarga. Pinjaman pun difasilitasi oleh kolonial Belanda, namun tidak berjalan lancar. Para peminjam lebih memilih untuk menggunakan pinjaman tersebut untuk membeli kebutuhan konsumtif. Bahkan, tidak sedikit juga yang menggunakan uang pinjaman tersebut untuk membiayai keperluan ritual adat Jawa (Dahlan, 2014: 338).

Kala itu, penduduk yang dipindahkan memang berasal dari wilayah Jawa Tengah, tepatnya dari Desa Bagelen Kabupaten Purworejo. Jumlah penduduk yang dipindahkan sekitar 155 KK. Pelaksanaan pemindahan dilakukan pada tahun 1905 yang merupakan gelombang pertama yang berlangsung hingga tahun 1911. Lokasi pemindahan $155 \mathrm{KK}$ dari Desa Bagelen berada di daerah hutan belantara di wilayah Pesawaran. Rute perjalanan melewati Gedongtataan Lampung Selatan yang dilakukan selama 5 hari perjalanan (Saroso, 2014). 
Periode kedua transmigrasi dilakukan pada tahun 1922. Lokasi yang dipilih kala itu berada di Kota Agung Lampung Selatan serta di wilayah Sukadana di wilayah Lampung Tengah.

Pola transmigrasi selain dilakukan secara berkelompok, juga dilakukan secara perseorangan atau disebut dengan istilah transmigrasi spontan. Jumlah warga yang menggunakan cara tersebut juga tidak dapat dibilang sedikit. Keinginan untuk melakukan transmigrasi spontan ke Provinsi Lampung sebagian besar disebabkan oleh gambaran peluang ekonomi atau pendapatan yang lebih besar melalui sektor pertanian dan perkebunan. Sementara kehidupan mereka di daerah asalnya sudah semakin sulit. Apalagi dengan adanya komunitas Jawa dan Sunda yang semakin membesar di Provinsi Lampung membuat mereka secara psikologis merasa tidak terasingkan di daerah baru tersebut. Lambat laun, pertambahan jumlah penduduk di Provinsi Lampung dari tahun ke tahun menjadi semakin pesat karena faktor transmigrasi tersebut. Data dari BPS Provinsi Lampung melalui perbandingan antara tahun 1961 hingga tahun 2019 menunjukkan tingkat kepesatan penduduk berdasarkan jumlah penduduk per $\mathrm{km}^{2}$.

Tabel 2. Jumlah dan Kepadatan Penduduk menurut Tahun (Jiwa) dan Kepadatan/Km2

\begin{tabular}{ccc}
\hline Tahun & Jumlah (Jiwa) & $\begin{array}{c}\text { Kepadata } \\
\mathbf{n} / \mathbf{k m}^{\mathbf{2}}\end{array}$ \\
\hline 1961 & 1.667 .511 & 52 \\
\hline 1971 & 2.775 .695 & 78 \\
\hline 1980 & 4.624 .785 & 131 \\
\hline 1990 & 6.015 .803 & 170 \\
\hline 2000 & 6.998 .535 & 189 \\
\hline 2010 & 7.634 .000 & 219,74 \\
\hline 2019 & 8.447 .740 & 243,99 \\
\hline
\end{tabular}

Sumber: Diolah dari data BPS Provinsi Lampung.

Terlihat pada Tabel di atas bahwa mulai tahun 1961 hingga tahun 2019, jumlah kepadatan penduduk semakin bertambah secara signifikan, yaitu sekitar
50\% lebih. Hal ini setidaknya dibantu oleh masuknya transmigran ke Provinsi Lampung selain angka pertumbuhan penduduk secara alamiah (kelahiran). Kenyataan yang dapat dilihat jelas dari peningkatan jumlah penduduk oleh masyarakat pendatang di Lampung adalah dari nama-nama wilayah mulai dari tingkat desa, kecamatan, hingga kabupaten beberapa di antaranya menggunakan namanama yang berasal dari wilayah-wilayah di Pulau Jawa seperti Pringsewu, Sukaraja, Ambarawa, Bandar Mataram, Sukabumi, Sukarame, dan sebagainya.

Kenaikan jumlah penduduk juga dirasakan oleh Kabupaten Lampung Selatan. Potensi kenaikan jumlah penduduk dapat dilihat baik dari kategori kelompok usia, jenis kelamin, keluarga, maupun jenis pekerjaan. Pada tabel di bawah ini ditampilkan data jumlah Penduduk Kabupaten Lampung Selatan berdasarkan kelompok usia yang dicrosstabulasikan dengan jenis kelamin.

Tabel 3. Persentase Penduduk menurut Kelompok Umur (10 Tahunan) dan Jenis Kelamin, 2018

\begin{tabular}{ccrr}
\hline \multirow{2}{*}{$\begin{array}{c}\text { Kelompok } \\
\text { Umur }\end{array}$} & \multicolumn{4}{c}{ Jenis Kelamin } \\
\cline { 2 - 4 } & $\begin{array}{c}\text { Laki- } \\
\text { laki }\end{array}$ & Perempuan & Jumlah \\
\hline$(1)$ & \multicolumn{1}{c}{$(2)$} & $(3)$ & \multicolumn{1}{c}{$(4)$} \\
\hline $0-9$ & 19.49 & 19.59 & 19.54 \\
\hline $10-9$ & 17.90 & 17.34 & 17.63 \\
\hline $20-29$ & 15.86 & 15.59 & 15.73 \\
\hline $30-39$ & 15.59 & 15.61 & 15.60 \\
\hline $40-49$ & 13.38 & 13.47 & 13.42 \\
\hline $50-59$ & 9.56 & 9.75 & 9.65 \\
\hline $60+$ & 8.21 & 8.64 & 8.42 \\
\hline & 100 & 100 & 100 \\
\hline
\end{tabular}

Sumber: Badan Pusat Statistik Kabupaten Lampung Selatan, 2018.

Terlihat pada tabel di atas bahwa jumlah penduduk Kabupaten Lampung Selatan dapat dilihat seperti kurva terbalik, karena kategori usia 0-9 adalah terbanyak dan semakin menurun hingga kategori 60+. Melalui data tersebut dapat diasumsikan 
bahwa jumlah angka kelahiran di Kabupaten Selatan masih tinggi dan semakin menurun berdasarkan kelompok usia (60+). Selain angka kelahiran yang tinggi, dapat diakibatkan juga banyaknya pendatang berusia muda yang tinggal dan menetap menjadi warga Lampung Selatan.

Kehidupan masyarakat Kabupaten Lampung banyak diwarnai oleh interaksi sosial dan budaya antara masyarakat asli dan masyarakat pendatang. Hal ini memberikan kesan bahwa proses adaptasi akan terus berjalan hingga tercapainya proses akulturasi dan adaptasi sosial. Tingkat ketercapaian kedua proses tersebut dapat tercapai salah satunya dapat didasarkan pada indikasi keterlihatan penduduk dalam pengetahuan baca tulis yang dapat dilihat pada tabel di bawah ini.

Tabel 4. Persentase Penduduk 15 Tahun ke Atas menurut Karakteristik dan

Kemampuan Membaca dan Menulis, 2018

\begin{tabular}{lccc}
\hline Karakteristik & $\begin{array}{c}\text { Hrf } \\
\text { Latin }\end{array}$ & $\begin{array}{c}\text { Hrf } \\
\text { Lainnya }\end{array}$ & $\begin{array}{c}\text { Melek } \\
\text { Hrf }\end{array}$ \\
\hline \multicolumn{1}{c}{$(1)$} & $(2)$ & $(3)$ & $(4)$ \\
\hline Jenis Kelamin & & & \\
\hline Laki-laki & 97.92 & 32.09 & 98.39 \\
\hline Perempuan & 93.48 & 30.79 & 94.45 \\
\hline Kelompok Pengeluaran & & \\
\hline 40\% Terbwh & 93.90 & 32.85 & 95.00 \\
\hline 40\% Tengah & 96.21 & 31.00 & 96.76 \\
\hline 20\% Teratas & 98.07 & 29.95 & 98.44 \\
\hline & 95,76 & 31,46 & 96,47 \\
\hline
\end{tabular}

Sumber: Badan Pusat Statistik Kabupaten Lampung Selatan, 2018.

Pada tabel di atas dapat dilihat bahwa kemampuan baca tulis (melek huruf) di Kabupaten Lampung Selatan sudah hampir mencapai 100 persen pada berbagai kalangan usia. Hal ini tentunya merupakan satu langkah keberhasilan Pemda Kabupaten Lampung Selatan melalui dinas terkait, yaitu Dinas Pendidikan Kabupaten Lampung Selatan, dalam usahanya yang dilakukan melalui berbagai program pendidikan baca tulis.
Melalui Dinas Pendidikan Kabupaten Lampung Selatan juga dapat dilihat kinerja sosialisasi upaya memajukan pendidikan di segala usia dan jenis kelamin. Melalui dua kelompok kategori tersebut setidaknya dapat menjawab capaian kinerja Dinas Pendidikan dalam memajukan pendidikan di segala usia dan jenis kelamin. Data capaian tersebut dapat dilihat pada tabel di bawah ini.

Tabel 5. Persentase Penduduk menurut Usia, Jenis Kelamin dan Status Pendidikan, 2018

\begin{tabular}{|c|c|c|c|c|c|c|}
\hline \multirow[t]{2}{*}{ Karakteristik } & \multirow[t]{2}{*}{$\begin{array}{l}\text { Tdk/ } \\
\text { blm } \\
\text { sklh }\end{array}$} & \multicolumn{3}{|c|}{ Masih Sekolah } & \multirow{2}{*}{$\begin{array}{c}\text { Tidak } \\
\text { bersekolah } \\
\text { lagi }\end{array}$} & \multirow[t]{2}{*}{ Jumlah } \\
\hline & & SD & SMP & SLTA & & \\
\hline (1) & (2) & (3) & (4) & (5) & (6) & $(7)$ \\
\hline \multicolumn{7}{|c|}{ Berumur 5 Tahun ke Atas } \\
\hline Laki-laki & 4.98 & 14.34 & 5.55 & 6.12 & 69.01 & 100.00 \\
\hline Perempuan & 8.89 & 13.86 & 5.66 & 5.84 & 65.74 & 100.00 \\
\hline \multicolumn{7}{|c|}{ Berumur 7-24 Tahun } \\
\hline L aki-laki & 0.61 & 37.83 & 15.66 & 17.08 & 28.82 & 100.00 \\
\hline Perempuan & 0.99 & 37.09 & 16.81 & 16.35 & 28.76 & 100.00 \\
\hline
\end{tabular}

Sumber: Badan Pusat Statistik

Kabupaten Lampung Selatan, 2018.

Terlihat pada tabel di atas bahwa tingkat pendidikan pada kelompok jenis kelamin hampir mencapai 100 persen namun dengan perbedaan yang signifikan pada jenis kelamin pada kolom tidak/belum pernah sekolah. Laki-laki (pada kolom tersebut) memiliki tingkat pendidikan yang lebih tinggi (4.98) daripada perempuan (8.89). Hal ini dapat diasumsikan bahwa kelompok jenis kelamin perempuan masih memiliki beban kultural sehingga pendidikan belum begitu menjadi prioritas dalam kehidupannya. Berbeda dengan laki-laki yang memang sudah dibiasakan untuk bersekolah karena dianggap dapat mempermudah mencari pekerjaan sebelum berumah tangga.

\section{c. Sosial Budaya}

Dalam kehidupan sosial budaya, masyarakat Kabupaten Lampung Selatan memiliki beragam aktivitas baik dalam kehidupan sosial, maupun ekspresi budaya 
yang dilaksanakan tidak secara spesifik pada suku bangsa tertentu. Contohnya adalah pada upacara daur hidup. Kelahiran, perkawinan, dan kematian pada masyarakat Lampung kerap dilaksanakan dengan mengundang tetangga yang notabene terdiri dari beragam suku bangsa. Bahkan, dalam upacara pemberian gelar, dalam adat istiadat Lampung Pepadun, siapa saja (tidak terkecuali berbeda suku bangsa) berhak untuk memperoleh gelar tersebut asalkan memenuhi syarat yang telah ditetapkan.

Kehidupan sosial budaya lainnya dapat dilihat dalam aktivitas keseharian masyarakat nelayan. Nelayan dan perahu adalah satu kesatuan yang tidak terpisahkan. Sama halnya dengan senapan yang harus berada di sisi tentara. Sosok, kemampuan, dan peralatan yang ada di dalam perahu nelayan menjadi bagian paling penting para nelayan saat melaut. Apabila salah satu peralatan pada perahu rusak atau bahkan tidak ada maka akan mengurangi semangat nelayan saat hendak mencari ikan.

Perahu atau kapal (perahu berukuran besar) sebagai pasangan hidup nelayan saat di laut memerlukan penanganan khusus agar dapat berfungsi maksimal saat mencari ikan. Salah satu bentuk penanganan khusus tersebut adalah cat yang menyelimuti seluruh lambung dan bagian dalam perahu.

Keharusan untuk mengecat seluruh bagian perahu kemudian menimbulkan satu kebiasaan dan kepercayaan dalam diri nelayan yang hingga kini masih dilakoni. Dari kebiasaan yang sudah berjalan cukup lama kemudian menimbulkan suatu keharusan untuk mengecat perahu pada waktu-waktu yang telah ditentukan.

Salah satu budaya masyarakat nelayan adalah menyangkut gaya hidup. Gaya hidup ini adakalanya merupakan serapan dari gaya hidup masyarakat di perkotaan, namun tidak sepenuhnya dilakukan. Terkadang sisi yang kurang bermanfaat pun tampak terlihat. Hal ini terutama tergambar dari kalangan generasi mudanya. Mereka terkadang menggunakan perumpamaan "biar rumah condong asal gulai balomak". Gambaran ini memberi makna kurang lebih bahwa meskipun kondisi rumahmu tumbang asalkan tetap makan enak.

Gambaran lain tentang masyarakat nelayan adalah kecenderungan untuk hidup "boros". Penghasilan hari ini akan dihabiskan saat itu juga. Hal ini pada akhirnya membuat kehidupan ekonomi nelayan tetap berada dalam keadaan yang tidak baik karena ketidakpastian jumlah penghasilan yang mereka peroleh. Apakah hari ini atau esok mereka akan memperoleh penghasilan atau tidak merupakan sebuah pertanyaan yang terkadang tidak begitu dipikirkan oleh nelayan. Walaupun demikian, gambaran kehidupan nelayan tersebut tidaklah sepenuhnya benar. Adakalanya mereka melaksanakan gaya hidup tersebut terutama di saat mereka (nelayan) mendapatkan hasil laut yang berlimpah. Mereka setidaknya akan merayakan perolehannya tersebut dengan cara membeli atau membuat sajian di luar kebiasaan sehari-hari.

Meski terkadang kurang begitu memperhatikan manajemen keuangan, namun khusus berkenaan dengan biaya sosial kenelayanan, masyarakat nelayan di Lampung Selatan umumnya atau di Desa Sukaraja khususnya seakan sudah terpola. Artinya, semangat kebersamaan dalam melakukan kontak sosial sudah terpatri dalam kehidupan masyarakat nelayan, dan sudah menjadi bagian dari kehidupan nelayan. Termasuk di dalamnya adalah iuran sosial yang digunakan untuk melakukan aktivitas sosial keagamaan, kemasyarakatan maupun aktivitas budaya, yang salah satunya adalah melakukan tradisi Syukuran Laut.

\section{Dari Ruwat Laut menjadi Syukuran Laut}

Ruwat Laut di Kecamatan Rajabasa, tepatnya di Desa Sukaraja Kec. Rajabasa Kab. Lampung Selatan sudah berlangsung 
sejak lama. Informan (M) mengatakan bahwa sejak beliau masih berumur 12 tahun (lahir tahun 1970), hingga saat ini (tahun 2019) Ruwat Laut sudah ada dan diikutinya. Informan $\mathrm{M}$ dan warga lainnya yang mengikuti tradisi Ruwat Laut berasal dari turunan Sunda (Serang Provinsi Banten). Kata turunan diartikan bahwa orangtua dan warga lainnya di Desa Sukaraja berasal dari wilayah Sunda yang hijrah dan menetap di Desa Sukaraja.

Pelaksanaan Ruwat Laut adalah sekitar tanggal 25 - 30 bulan Safar atau Muharram. Penentuan antara dua bulan menurut kalender Islam tersebut tidak didasarkan atas perhitungan tertentu namun lebih didasarkan atas faktor kecukupan dalam proses pembiayaan. Dengan demikian, apabila pada dana yang terkumpul pada bulan Safar tidak dapat terpenuhi, maka akan dilanjutkan proses pengumpulan sumbangan hingga dapat terlaksana pada bulan Muharram.

Pengertian Ruwat Laut pada masa dulu adalah sama dengan ritual Ruwat Laut seperti yang dilakukan di Kecamatan Kalianda pada tahun 2015. Pada waktu itu tahapan dalam bentuk prosesi pelarungan, sesajen, pertunjukan wayang golek adalah biasa dilakukan masyarakat Nelayan Rajabasa. Saat ini, Ruwat Laut dengan prosesi tersebut sudah tidak dapat dilaksanakan lagi karena faktor biaya yang cukup besar. Dana yang diperoleh dari sumbangan para nelayan di Desa Sukaraja tidak dapat mencukupi untuk mengadakan Ruwat Laut seperti itu.

Dalam prosesi Ruwat Laut, setiap perahu diberi jatah sekitar Rp 300.000,untuk mengikuti dan menjalankan tradisi Ruwat Laut. Pendanaan dilakukan dengan mengumpulkan sumbangan dari nelayan yang dapat dikatakan tidak besar. Bahkan ada yang menyumbang hanya Rp 2.000 per hari. Proses pencarian dana yang berlangsung kontinyu diharapkan dapat mencukupi kebutuhan biaya Ruwat Laut yang sedikitnya memerlukan Rp20.000.000,-. Apabila ditambahkan dengan hiburan seperti organ tunggal ditambah sekitar Rp 4.000.000,- Untuk saat ini kemampuan mencapai dana $\mathrm{Rp}$ 4.000.000,- sudah tak dapat dipenuhi lagi. Berbeda dengan masa-masa dahulu yang mampu mencapai bahkan Rp 15.000.000,untuk menyewa organ tunggal.

Tradisi Ruwat Laut yang identik dengan pelarungan kepala kerbau berdasarkan kondisi pendanaan yang tidak memadai mengakibatkan nelayan di Desa Sukaraja, Kecamatan Rajabasa, Kabupaten Lampung Selatan tidak mampu melaksanakannya. Apalagi ditambah dengan adanya persepsi adat masyarakat Lampung yang mengungkapkan bahwa tahapan pelarungan kepala kerbau dianggap kurang sesuai apabila dilaksanakan dalam bentuk "pengorbanan" makhluk hidup, yang dalam hal ini adalah kepala kerbau. Unsur penghormatan kepada alam (lautan) berikut unsur astral di dalamnya sebaiknya dilakukan dengan cara agama (Islam).

Sama halnya dengan masyarakat nelayan di Kalianda, tradisi Ruwat Laut pada masyarakat nelayan di Desa Sukaraja, Kecamatan Rajabasa, Kabupaten Lampung Selatan juga demikian halnya. Ditambah lagi dengan kebutuhan dana yang sangat besar membuat pelaksanaan Ruwat Laut sangat sulit dilaksanakan. Namun demikian, Ruwat Laut menjadi semacam kebutuhan budaya yang telah tertanam kuat dalam diri masyarakat nelayan, menjadi pemicu untuk tetap dilaksanakan meskipun dengan jumlah dana minim.

Upaya meminimalisir jumlah biaya yang dipadukan dengan upaya penyesuaian dengan karakter budaya masyarakat Lampung menghasilkan formula baru dalam pelaksanaan Ruwat Laut, yang kemudian dinamakan Syukuran Laut. Kata "Syukuran" menurut informan merupakan kata yang umum digunakan dan dipahami oleh sebagian besar masyarakat untuk mengarahkan wawasan berpikir pada satu kegiatan ritual yang bertujuan mengungkapkan rasa syukur atas anugerah yang diberikan Tuhan kepada manusia. Sebenarnya kata "Syukuran" memiliki 
persamaan dengan istilah dalam tradisi ritual seperti ruwat, ruwatan, ngaruwat, hajat, dan hajatan. Walaupun demikian, kata "Syukuran" digunakan untuk membedakan dengan ritual yang dilaksanakan dalam Ruwat Laut.

Dalam pelaksanaannya, Syukuran Laut tidak melakukan prosesi yang membutuhkan biaya besar, seperti pelarungan kepala kerbau dan berbagai pertunjukan hiburan. Oleh sebab itu, pemangkasan dua tahapan tersebut menghasilkan jumlah dana yang dibutuhkan dalam pelaksanaan Syukuran Laut jauh lebih ringan.

Syukuran Laut adalah kata pengganti dari tradisi Ruwat Laut. Penggantian nama tradisi ini sudah berlangsung sejak dua tahun yang lalu. Pada tahun 2019, proses pendanaan untuk mengadakan Syukuran Laut sudah berjalan dan dilaksanakan sekitar bulan Safar atau Muharram.

Perihal waktu pelaksanaan di antara dua bulan Islam tersebut juga menjadi bahan pertanyaan dari sebagian masyarakat yang menganggap Syukuran Laut dalam perspektif kemusyrikan. Selain pelarungan kepala (kerbau) mereka juga mempertanyakan mengapa prosesi syukuran mesti dilakukan pada dua bulan tersebut (Safar/Muharram) padahal seluruh bulan dalam kalender Islam tidak ditandai baik dan buruknya. Terlepas dari pertanyaan tersebut, Syukuran Laut menurut nelayan di Desa Sukaraja Kec. Rajabasa Kab. Lampung Selatan dianggap sebagai ungkapan kegembiraan atas rezeki yang diberikan Sang Pencipta yang diperoleh selama melaut. Ungkapan kegembiraan atas rezeki yang diperoleh adalah relatif dalam pengertian bukan hanya saat memperoleh rezeki yang berlimpah saja mereka baru mengadakan Syukuran Laut. Hal ini diperoleh keterangan dari informan bahwa beberapa tahun belakangan ini malah penghasilan mencari ikan di laut relatif lebih sedikit akibat dari maraknya kapal-kapal besar dari daerah lain yang juga mencari ikan di perairan yang sama. Syukuran Laut juga dianggap tidak memiliki kaitan dengan tragedi tsunami yang terjadi beberapa waktu yang lalu. Perihal ampuh atau tidaknya prosesi Syukuran Laut tidak dijadikan alasan nelayan atas kerugian atau kecelakaan yang terjadi saat melaut. Mereka lebih memfokuskan diri pada pelaksanaan kebutuhan budaya yang diupayakan tetap dilakukan setiap tahunnya

Proses pendanaan dilakukan setelah proses musyawarah yang dilakukan oleh nelayan. Hasilnya adalah disahkannya ketua panitia beserta jajaran di bawahnya dan jumlah biaya yang dikeluarkan untuk ritual Syukuran Laut. Proses pemilihan ketua panitia Syukuran Laut di Desa Sukaraja Kecamatan Rajabasa ini dilakukan secara bergantian. Tujuannya adalah agar adanya pemerataan dan sekaligus merasakan bagaimana beratnya menjadi ketua panitia Syukuran Laut. Ketua panitia diibaratkan sebagai sebuah jabatan yang lumayan berat karena harus mampu mengawasi proses pendanaan sekaligus pelaksanaan. Apabila pada saat pelaksanaan ada salah satu bagian yang kurang dana, maka ketua panitia bertanggungjawab menanggulanginya. Salah satu upaya pemenuhan dana adalah dengan cara berhutang dan akan diungkapkan saat kumpulan setelah pelaksanaan Syukuran Laut. Informan (M) sudah menjabat sebagai ketua panitia Syukuran Laut selama 3 periode berturutturut (3 tahun) dan berakhir pada tahun 2018. Pada tahun 2019 ketua panitia kemudian diganti oleh warga dari wilayah setempat.

Setelah syukuran, para nelayan kembali melakukan kumpulan. Tujuannya adalah untuk melaporkan jumlah dana yang keluar. Ada juga laporan mengenai jumlah utang yang dikeluarkan saat pelaksanaan. Melalui kumpulan tersebut, setidaknya ada transparansi dalam pengelolaan keuangan yang memang menjadi bagian sensitif bagi pelaksanaan Syukuran Laut. Utang dalam pelaksanaan 
Syukuran Laut biasanya dilunasi setelah pelaksanaan Syukuran Laut. Sengaja dibuat demikian karena selama pelaksanaan pun masih banyak biaya tidak terduga yang memaksa panitia merogoh kocek pendanaan, atau bahkan meminjam di kala dana kegiatan sudah habis terpakai untuk pembiayaan sektor pendukung lainnya.

Pelaksanaan Syukuran Laut di Desa Sukaraja Kecamatan Rajabasa berada di pantai yang masih dalam lingkup wilayah Desa Sukaraja. Waktu pelaksanaan syukuran biasa dilakukan mulai pukul 06.00 WIB hingga pukul 11.00 WIB. Pada pukul 06.00 WIB, masyarakat yang mengikuti Syukuran Laut sudah berkumpul termasuk ibu-ibu yang berperan sebagai pengolah masakan. Di lokasi acara, tenda biasanya sudah disiapkan sejak kemarin sore sehingga pada pagi hari sudah siap untuk dipergunakan.

Pada pagi hari, pengeras suara di masjid biasanya digunakan untuk mengumumkan agar warga diharapkan dapat mengikuti Syukuran Laut. Warga masyarakat dalam pengertian ini adalah seluruh masyarakat di lokasi sekitar pemukiman nelayan. Oleh karena itu, peserta Syukuran Laut tidak hanya mutlak dilakukan oleh nelayan saja, tetapi warga nonnelayan juga menjadi bagian tidak terpisahkan dalam mengikuti Syukuran Laut. Tidak hanya warga sekitar yang mengikuti prosesi Syukuran Laut, panitia Syukuran Laut juga mengundang dinas terkait, lembaga kenelayanan, dan ketua nelayan di Kabupaten Lampung Selatan. Diperkirakan pengikut Syukuran Laut beserta dengan undangannya sekitar 300 orang.

Biaya pembelian bahan konsumsi termasuk lumayan besar. Kebutuhan daging ayam dalam Syukuran Laut sekitar 100 ekor, beras sebanyak 1 kuintal. Belum lagi dengan berbagai bahan bumbu dan jenis masakan lainnya seperti bihun, buncis, wortel, kentang, cabe merah, cabe hijau, dan sebagainya. Dengan perkiraan bahan baku masakan tersebut, panitia
Syukuran Laut setidaknya membutuhkan minimal Rp 2.000.000,-.

Dalam Syukuran Laut ini, tidak ada pembelian kerbau. Unsur musyrik menjadi salah satu hal yang kerap didengungkan menjadikan ritual pelarungan kepala kerbau tidak dilakukan. Sebagai ganti daging kerbau yang biasa menjadi hidangan prosesi Ruwat Laut, Syukuran Laut menggantikannya dengan dua ekor kambing / domba. Seluruh bagian daging kambing / domba termasuk bagian kepalanya dijadikan bahan untuk konsumsi peserta Syukuran Laut.

Acara pertama dilakukan dalam bentuk pembacaan manakib Syek Abdul Qadir Jaelani atau dalam bahasa setempat disebut dengan istilah Macasyekh. Prosesi Macasyekh dilakukan dengan mengudang kyai atau pelaku yang biasa melakukan prosesi tersebut. Anggaran untuk melakukan prosesi tersebut sebanyak $\mathrm{Rp}$ 500.000,- untuk membayar kyai yang membacakan Macasyekh.

Dalam proses Macasyekh, ada syarat sesajen yang harus dipenuhi, yaitu rokok tujuh macam, kue tujuh rupa dan air tujuh rupa (rasa), serta kemenyan. Syarat sesajen tersebut nampak sama dengan prosesi pembacaan Macasyekh yang biasa dilakukan masyarakat di Kabupaten Serang dan Pandeglang Provinsi Banten.

Setelah Macasyekh berakhir dilanjutkan dengan ceramah. Materi ceramah adalah seputar penghormatan kepada junjungan Nabi Besar Muhammad SAW. beserta para ulama besar lainnya. Dilanjutkan dengan materi ceramah tentang perlakuan manusia terhadap alam (laut) yang harus harmonis dengan tidak lupa membaca doa sebelum melakukan setiap aktivitas di laut.

Materi ceramah yang telah selesai lalu disambung dengan membaca surah Yasin. Pembacaan surah Yasin merupakan acara yang biasa dilakukan untuk menghormati dan mendoakan orang yang sudah meninggal. Tujuan pembacaan surah Yasin tersebut adalah agar arwah sanak keluarga, tetangga, hingga korban lain 
yang meninggal di laut mendapat tempat yang layak disisi-Nya.

Terakhir adalah membaca doa. Materi doa yang disampaikan biasanya ditujukan untuk keselamatan warga dalam melakukan aktivitas di laut. Selain itu juga mengharapkan rida Allah SWT. untuk memberikan limpahan rezeki saat nelayan mencari ikan di laut.

Doa disampaikan oleh ustaz atau tokoh agama masyarakat setempat. Untuk mengundang tokoh agama di wilayah lainnya tentu akan membutuhkan biaya yang lebih besar. Setelah selesai membaca dilanjutkan dengan makan bersama. Seluruh hidangan yang disediakan tidak ada yang dibawa pulang. Seluruh hidangan habis saat itu juga disantap oleh peserta Syukuran Laut. Apabila ada sisa makanan maka akan dibungkus dan dibawa pulang oleh panitia untuk dibagikan kepada warga yang dianggap kurang mampu. Rangkaian seluruh acara Syukuran Laut diupayakan tidak melampaui waktu shalat zuhur. Biasanya, perkiraan selesai membaca doa sekitar pukul 11.00 WIB.

\section{PENUTUP}

Demikianlah sebuah karya budaya yang benama Syukuran Laut dilaksanakan di Desa Sukaraja Kecamatan Rajabasa Kabupaten Lampung Selatan. Sebuah karya budaya masyarakat pendatang yang berusaha beradaptasi dengan budaya masyarakat setempat (Lampung Selatan) yang mayoritas beragama Islam.

Sebenarnya jumlah penganut agama (Islam) di Lampung Selatan tidak menjadi pedoman dalam melakukan ekspresi budaya pada masyarakat pendatang. Mereka (masyarakat pendatang) di daerah asalnya, baik di Jawa Tengah, Jawa Barat, dan Banten juga memiliki jumlah penganut agama Islam yang lebih besar jika dibandingkan dengan agama lainnya. Namun dalam hal ini, kondisi kekinian budaya masyarakat Lampung sudah banyak menyerap unsur agama (Islam) sebagai pedoman dalam melakukan ekspresi budaya sehingga tahap-tahap dari pelaksanaan karya budaya yang nampak kentara bertentangan dengan agama Islam menjadi sebuah masalah dan harus diselesaikan. Pelarungan kepala kerbau yang menjadi tahap puncak dalam tradisi Ruwat Laut dalam persepsi budaya Lampung dianggap bertentangan karena melanggar unsur kepatuhan selain kepada Allah SWT. Ditambah lagi dengan penguatan yang dilakukan pimpinan daerah kala itu yang tidak menghendaki adanya pelarungan kepala kerbau dalam tradisi Ruwat Laut.

Dinamika budaya masyarakat Lampung memang untuk kondisi saat ini sangat berbeda dengan kondisi zaman dahulu. Apabila dilihat dari perjalanan sejarah budaya masyarakat Lampung akan sangat kontras hasilnya. Salah satu tradisi yang mewajibkan persembahan makhluk hidup untuk kegiatan ritual adalah dalam pelaksanaan Tari Dibingi. Setiawan (2018: 224) mengatakan bahwa sebelum pelaksanaan Tari Dibingi pada masa lalu diwajibkan untuk melakukan penyembelihan hewan kerbau/sapi. Daging hewan kurban tersebut kemudian dibagikan kepada sesepuh, panitia, dan warga.

Agama Islam muncul di Sumatera sekitar tahun 1292 namun proses penyebarannya belum begitu jelas. Sementara itu, di wilayah Lampung, Islam menyebar dan dianggap sebagai agama resmi oleh masyarakat Lampung sekitar abad ke-16 (Silaban, 1997: 39). Setelah agama Islam masuk dan menyebar di masyarakat Lampung, unsur kepercayaan asli masyarakat Lampung kemudian tersudutkan bahkan punah. Wawasan baru dengan konsep Islam kemudian mengemuka dan menjadi salah satu alasan terjadinya perbedaan persepsi dalam tradisi Ruwat Laut.

Pandangan bahwa pelarungan kepala kerbau merupakan wujud dari pengakuan adanya makhluk halus atau sosok gaib yang menghuni dan menguasai lautan. Dalam agama Islam pun mengakui adanya keberadaan jin (makhluk halus). Adanya 
kesamaan pandangan antara agama dan budaya dalam kasus Ruwat Laut ini kemudian didefinisikan dengan cara yang berbeda. Menurut pandangan budaya Lampung bahwa interaksi manusia dengan makhluk halus harus ditangani dengan cara-cara agama (Islam). Wujud dari definisi itulah yang kemudian diterjemahkan dalam bentuk Syukuran Laut yang dilaksanakan di Desa Sukaraja, Kecamatan Rajabasa, Kabupaten Lampung Selatan.

\section{DAFTAR SUMBER}

Badan Pusat Statistik Kabupaten Lampung Selatan, 2018. Statistik Kesejahteraan Rakyat Kabupaten Lampung Selatan 2018. Kaliada: Badan Pusat Statistik Kabupaten Lampung Selatan.

Dahlan, M. H. (2014). Perpindahan Penduduk dalam Tiga Masa: Kolonisasi, Kokuminggakari, dan Transmigrasi di Provinsi Lampung (1905-1979). Jurnal Patanjala, 6(3), 335-348.

IPDS BPS Kabupaten Lampung Selatan, 2018. Kabupaten Lampung Selatan dalam Angka 2018, Kalianda: BPS Kabupaten Lampung Selatan.

Kartikasari, T. dan Agustina, D. (1999) Upacara Melabuh di Palabuhanratu, Jakarta: Direktorat Sejarah dan Nilai Tradisional, Direktorat Jenderal Kebudayaan, Departemen Pendidikan dan Kebudayaan.

Kartodirdjo, S., Poesponegoro, M. D., \& Notosusanto, N. (1973). Sejarah Nasional Indonesia Jilid V. Jakarta: Depdikbud.

Ruslan, I. (2014). Religiositas Masyarakat Pesisir: (Studi Atas Tradisi "Sedekah Laut" Masyarakat Kelurahan Kangkung Kecamatan Bumi Waras Kota Bandar Lampung). Jurnal Al-AdYaN, Vol. 9 (2).

Ruslan, I. (2019). “Tradisi Islam Pesisir: Ritual Ngumbai Lawok di Kabupaten Pesisir Barat Provinsi Lampung", dalam $\mathrm{Al}$ Adyan: Jurnal Studi Lintas Agama, 14 (2).

Saputra, R. D. (2011). Tradisi Ruwat Laut (Ngumbai Lawok) di Kelurahan
Kangkung Kecamatan Teluk Betung Selatan Kota Bandar Lampung dalam Perspektif Hukum Islam. Skripsi. Jakarta: Fakultas Syariah dan Hukum, Universitas Syarif Hidayatullah.

Saroso, O. (2014, 6 Februari). Sejarah Transmigrasi di Lampung: Mereka Datang dari Bagelen. Diakses dari https://www.teraslampung.com/sejarahkolonisas-di-lampung-mereka-datangdari-bagelen/

Setiawan, I. (2018). Tari Dibingi: Sebuah Upaya Penggalian Data Awal Tarian Tradisional yang Terancam Punah di Kabupaten Pesisir Barat, Lampung. Patanjala, 10 (2), 219 - 234.

Silaban, M. (1997). Sejarah Daerah Lampung. Jakarta: Bagian Proyek Pengkajian dan Pembinaan Nilai-nilai Budaya Lampung, Departemen Pendidikan dan Kebudayaan.

Wiryawan, B., Marsden, B., Susanto, H.A., Mahi, A.K., Ahmad, M., Poespitasari, H. (Editor). (1999). Atlas Sumberdaya Wilayah Pesisir Lampung. Bandar Lampung: Kerjasama PEMDA Provinsi Lampung dengan Proyek Pesisir (Coastal Resources Center, University of Rhode Island dan Pusat Kajian Sumberdaya Pesisir dan Lautan, Institut Pertanian Bogor). 